relativa e distante deveria ser a "estima pública" à instituição, mencionada por Rui?

Em suma, deve-se aguardar com ansiedade o prosseguimento da obra, que por certo já está se tornando ponto de referência obrigatório para o estudo dêsses primeiros momentos da República.

\title{
CARLOS GUILHERME MOTA
}

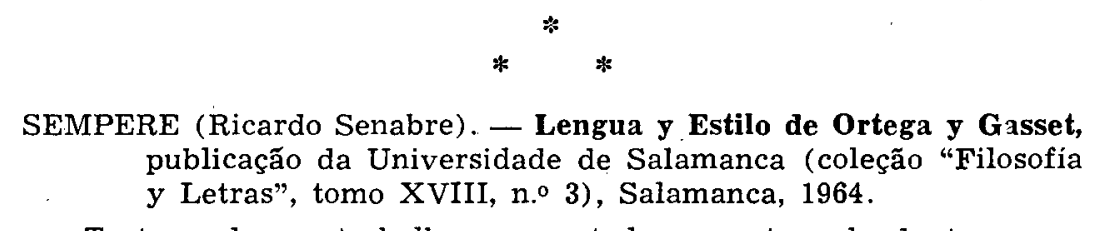

Trata-se de um trabalho apresentado como tese de doutoramento na Faculdade de Filosofia e Letras de Salamanca, em junho de 1963 (Prêmio Especial).

Procurando evitar o que chama de "cansativas polêmicas acêrca de sua condição de filósofo", Sempere analisa Ortega como escritor, detendo-se exclusivamente em seu valor litrário, embora admita, sem entrar em considerações mais aprofundadas, qu a filosofia condiciona, de certa maneira, seu estilo.

O livro aborda, pormenorizadamente, a língua, a estrutura da prosa, a metáfora, o mundo das imagens, o popularismo, a ironia e o humor, a dramatização, que caracterizam a obra de Ortega, sempre do ponto de vista lingüístico; não deixa, entretanto, de enquadrá-lo dentro de um mundo cultural, que foi a Geração de 98 e o Novecentismo.

O autor não pretende esgotar o assunto, já que, como salienta, apesar da grande influência que têve em sua época, Ortega não foi ainda devidamente estudado. Sua tese traz, explìcitamente, a idéia de suscitar novos trabalhos.

ANA MARIA DE ALMEIDA CAMARgo 